

\section{DISCLAIMER}

This report was prepared as an account of work sponsored by an agency of the United States Government. Neither the United States Government nor any agency Thereof, nor any of their employees, makes any warranty, express or implied, or assumes any legal liability or responsibility for the accuracy, completeness, or usefulness of any information, apparatus, product, or process disclosed, or represents that its use would not infringe privately owned rights. Reference herein to any specific commercial product, process, or service by trade name, trademark, manufacturer, or otherwise does not necessarily constitute or imply its endorsement, recommendation, or favoring by the United States Government or any agency thereof. The views and opinions of authors expressed herein do not necessarily state or reflect those of the United States Government or any agency thereof. 


\section{DISCLAIMER}

Portions of this document may be illegible in electronic image products. Images are produced from the best available original document. 


\section{NOTICE}

This report was prepared as an account of work sponsored by the United States Government. Neither the United States nor the U.S. DOE, nor any of its employes, nor any of its contractors, subcontractors or their employes, makes any warranty, expressed or implied, or assumes any legal liability or responsibility for any third party's use or the results of such use of any information, apparatus, product or process disclosed in this report, or represents that its use by such third party would not infringe privately owned rights.

Printed in the United States of America

Available from

DOE Technical Information Center

P.O. Box 62

Oak Ridge, TN 37830

NTIS price codes

Printed Copy: A 03

Microfiche copy: A01 


\title{
THE EFFECT OF PRODUCT FORM UPON FATIGUE-CRACK GROWTH BEHAVIOR IN ALLOY 718-ADDITIONAL RESULTS
}

\section{Hanford Engineering Development Laboratory}

\author{
L.A. James
}

August, 1980

\section{MASTER}

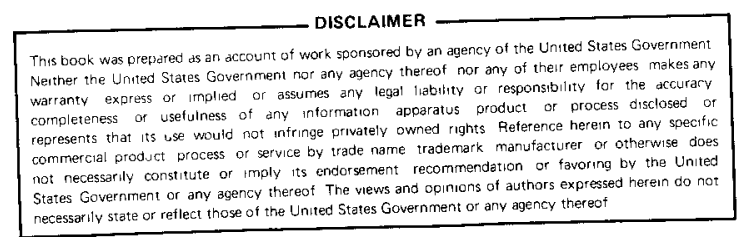

DISTRIBUTION OF THIS OOCUMENT IS UNLIMITEO
HANFORD ENGINEERING DEYELOPMENT LABORATORY Operated by Westinghouse Hanford Company P.0. Box 1970 Richland, Wh 99352 A Subsidiary of Westinghouse Electric Corporation Prepared for the U.S. Department of Energy under Contract No. DE-AC1476FF02170 


\section{THE EFFECT OF PRODUCT FORM UPON FATIGUE-CRACK}

\section{GROWTH BEHAVIOR IN ALLOY 718 - ADDITIONAL RESULTS}

\section{By}

Lee A. James

\section{ABSTRACT}

A previous study had characterized the fatigue-crack growth behavior of four wrought product forms (sheet, plate, bar and forging) from a single heat of Alloy 718 and concluded that there were no consistent trends in the crack growth rate results that could be attributed to product form variability. The present study adds one additional product form (gas-tungsten-are weldments) from the same heat, and compares the behavior to that exhibited by the wrought product forms. Two different precipitation heat-treatments were employed at each of five test temperatures. 


\section{CONTENTS}

\section{Page}

Abstract i i i

Figures

vi

Tables

vij

I. INTRODUCTION

1

II. EXPERIMENTAL PROCEDURE

III. RESULTS AND DISCUSSION

IV. SUMMARY AND CONCLUSIONS

V. REFERENCES 


\section{FIGURES}

Figure

Page

1. Comparison of Crack Growth Behavior in Alloy 718 Weldments and Wrought Product Forms (Sheet, Plate, Bar, and Forgings) at $24^{\circ} \mathrm{C}\left(75^{\circ} \mathrm{F}\right)$

2. Comparison of Crack Growth Behavior in Alloy 718 Weldments and Wrought Product Forms (Sheet, Plate, Bar, and Forgings) at $316^{\circ} \mathrm{C}\left(600^{\circ} \mathrm{F}\right)$

3. Comparison of Crack Growth Behavior in Alloy 718 Weldments and Wrought Product Forms (Sheet, Plate, Bar, and Forgings) at $427^{\circ} \mathrm{C}\left(800^{\circ} \mathrm{F}\right)$

4. Comparison of Crack Growth Behavior in A1loy 718 Weldments and Wrought Product Forms (Sheet, Plate, Bar, and Forgings) at $538^{\circ} \mathrm{C}\left(1000^{\circ} \mathrm{F}\right)$

5. Comparison of Crack Growth Behavior in Alloy 718 Weldments and Wrought Product Forms (Plate, Bar, and Forgings) at $649^{\circ} \mathrm{C}\left(1200^{\circ} \mathrm{F}\right)$ 


\section{TABLES}

Table $\quad$ Page

1. Chemical Analyses (Percent by Weight) 4

2. Post-Weld Precipitation Heat Treatments for Alloy 718

3. Crack Growth Equation Constants 14 


\section{THE EFFECT OF PRODUCT FORM UPON FATIGUE-CRACK}

\section{GROWTH BEHAVIOR IN ALLOY 718 - ADDITIONAL RESULTS}

$$
\text { (AF-15-10-15) }
$$

\section{INTRODUCTION}

Alloy 718 is a precipitation-hardenable nickel-base superalloy that is employed extensively in structural applications in the nuclear, aerospace, and petrochemical industries where high strength, creep resistance, and corrosion resistance at elevated temperatures are important design considerations. Such structures are often subjected to cyclic loadings in service, and the possibility therefore exists for subcritical extension of defects, should such defects be present in the appropriate size, shape, and location. The analysis techniques of linear-elastic fracture mechanics (LEFM) are quite usefur in estimating the in-service extension of such flaws, but their usage requires knowledge of the fatigue-crack propagation (FCP) behavior of the structural alloy tested under the appropriate conditions.

Considerable work has already been done in characterizing FCP behavior in Alloy 718 at elevated temperatures. Variations in the crack growth behavior have been noted ${ }^{(1-5)}$ between different heats of this alloy. The underlying cause(s) of these differences has been at least partially obscured by the fact that the various material heats represented different product forms and melt practices, as well as having subtle differences in chemical composition which could influence precipitation kinetics. In order to evaluate at least one of these potential influences, a series of experiments ${ }^{(6)}$ was conducted to characterize potential product form variations in the FCP behavior. Reference 6 studied crack growth behavior in four wrought product forms (sheet, plate, bar, and a forging) from the same heat of A1loy 718 at a number of test temperatures, and concluded that there was no apparent influence of product form upon the FCP behavior. Since that time, specimens representing a fifth product form (weldments) from that same heat of 
Alloy 718 have been tested. Therefore, the objective of this report is to include these results in the overall assessment of potential product form variations. 


\section{EXPERIMENTAL PROCEDURE}

The heat employed in this study was Cabot-Stellite heat 2180-6-9457. This heat, produced in several different product forms, was procured by the Idaho National Engineering Laboratory (INEL) to serve as a reference heat for Department of Energy programs. The thermomechanical history and properties of this heat are well-documented in Reference 7 . The earlier study ${ }^{(6)}$ on potential product form influence upon FCP behavior examined four product forms: $1.57 \mathrm{~mm}(0.063 \mathrm{inch})$ sheet, $12.7 \mathrm{~mm}(0.5 \mathrm{inch})$ plate, $50.8 \mathrm{~mm}(2.0$ inch) diameter bar, and a forging with a 5:1 upset ratio. The present study examines one additional product form: gas-tungsten-arc (GTA) weldments in $19.1 \mathrm{~mm}$ ( 0.75 inch) plate employing $1.14 \mathrm{~mm}(0.045$ inch) diameter weld filler wire. Both the base metal (plate) and the weld filler metal were from heat 2180-6-9457. Ladle and check analyses for all of the product forms studied are given in Table 1 . The minor compositional variations noted are generally within measurement accuracies.

Two different post-weld precipitation heat-treatments were employed in this study: the "conventional" heat-treatment (CHT) as employed in ASTM A637, AMS 5596, etc., and a "modified" heat-treatment (MHT) developed at the INEL to improve the toughness of weldments in Alloy $718 .^{(8)}$ The two heattreatments are detailed in Table 2, and the resulting tensile properties for the wrought product forms are given in Reference 7.

Standard Compact Type Specimens (see ASTM E647-78T) were employed in the crack growth tests. The specimens had width (W) and thickness (B) dimensions of approximately $29.31 \mathrm{~mm}(1.154 \mathrm{inch})$ and $7.62 \mathrm{~mm}(0.3 \mathrm{inch})$, respectively. The specimens were oriented with the notch (and hence the nominal direction of crack extension) parallel to the direction of welding and centered within the deposited weld metal. The weldments were of the "vee groove" design.

Fatigue cycling was done on servo-controlled MTS testing machines operating in the load-control mode using a sinusoidal waveform. All testing was done 
TABLE 1

CHEMICAL ANALYSES (PERCENT BY WEIGHT) ${ }^{(a)}$

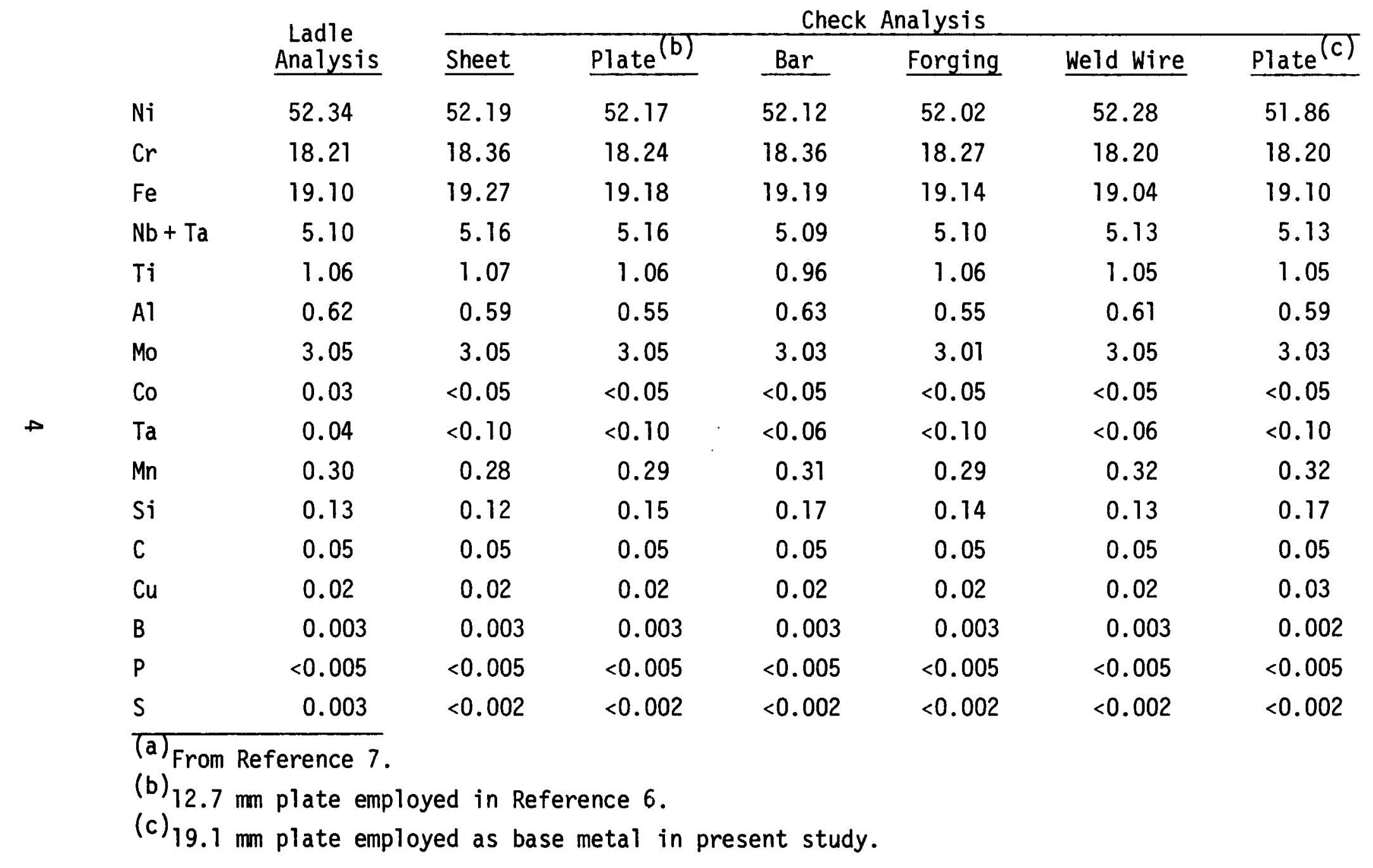


TABLE 2

POST-WELD PRECIPITATION HEAT TREATMENTS FOR ALLOY 718

\section{Conventional Heat Treatment}

Annealed at $954^{\circ} \mathrm{C}$, air cooled to room temperature.

Aged 8 hours at $718^{\circ} \mathrm{C}$, furnace cooled to $621^{\circ} \mathrm{C}$ and held at $621^{\circ} \mathrm{C}$ for a total aging time of 18 hours.

Air cooled to room temperature.

Modified Heat Treatment (Developed by Idaho National Engineering Laboratory) Solution annealed 1 hour at $1093^{\circ} \mathrm{C}$, cooled to $718^{\circ} \mathrm{C}$ at $55^{\circ} \mathrm{C} /$ hour . Aged 4 hours at $718^{\circ} \mathrm{C}$, cooled to $621^{\circ} \mathrm{C}$ at $55^{\circ} \mathrm{C} /$ hour.

Aged 16 hours at $621^{\circ} \mathrm{C}$, air cooled to room temperature. 
at a cyclic frequency of $0.667 \mathrm{~Hz}(40 \mathrm{cpm})$ except at room temperature where frequency is not expected to be an important variable. The stress ratio $\left(R=K_{\min } / K_{\max }\right)$ was 0.05 for all tests.

Tests were conducted at five temperatures: $24^{\circ} \mathrm{C}\left(75^{\circ} \mathrm{F}\right), 316^{\circ} \mathrm{C}\left(600^{\circ} \mathrm{F}\right)$, $427^{\circ} \mathrm{C}\left(800^{\circ} \mathrm{F}\right), 538^{\circ} \mathrm{C}\left(1000^{\circ} \mathrm{F}\right)$, and $649^{\circ} \mathrm{C}\left(1200^{\circ} \mathrm{F}\right)$. The specimens were tested in an air-circulating furnace where temperatures were controlled to within $\pm 1^{\circ} \mathrm{C}$. Crack lengths were determined periodically throughout each test using a travelling microscope. Fatigue-crack growth rates (da/dN) were calculated using the "secant method", $(9)$ and the associated stress intensity factors (K) were calculated using the expression in ASTM E647-78T.

In general, the testing and data analysis methods of ASTM E647-78T were employed in this study. LEFM validity was assured by limiting crack-tip plasticity in the uncracked ligaments by employing a "flow stress criterion". (10) Virtually all of the data reported in this study satisfied the flow stress criterion, and the few exceptions (e.g., see Figures $1 b$ and $3 b$ ) are identified by closed data symbols. 


\section{RESULTS AND DISCUSSION}

The results of this study are given in Figures 1-5. The format for each figure is the same: material given the conventional heat-treatment is shown on the left, and that given the modified heat-treatment is shown on the right. In each case, least-squares regression lines are fitted through each set of data (see Table 3 for the regression constants). The regression lines for the wrought product forms (sheet, plate, bar, and forgings) from heat 2180-6-9457 are plotted as dashed lines for comparison purposes. The scatter bands for the wrought product forms are also shown as dotted lines.

Comparing the regression lines for the present study on weldments (the solid lines in Figures (-5) with the regression lines for the previous study ${ }^{(6)}$ involving wrought product forms from the same heat (the dashed lines) shows that in most cases, the weldments exhibit slightly higher crack growth rate curves. This is in contrast to the findings of Reference 6 which showed no consistent trend in terms of product form for sheet, plate, bar, or forgings over the wide range of conditions covered. It should be noted that the slight tendency for higher crack growth rates in the weldments is not large, and there is generally considerable overlap between the scatter bands of the weldment data and those for the wrought data. Increases in FCP rates in Alloy 718 weldments relative to those in wrought Alloy 718 have been noted previously. $(11,12)$ However, the previous studies compared weldments and wrought materials from different heats, thereby raising the possibility of heat-to-heat variability as well as the differences between weldments and wrought materials.

It will be noted that in some of the curves (e.g., Figures $1 a, 1 b, 2 a, 2 b$, $3 b)$, the data for the weldment specimens exhibits a change to a steeper slope at the higher values of $\Delta K$. This sort of trend is fairly typical of crack growth rate curves for many types of materials, and is often associated with the approach to instability conditions (either in terms of fracture toughness, plastic limit load, etc.). The curves for the wrought 


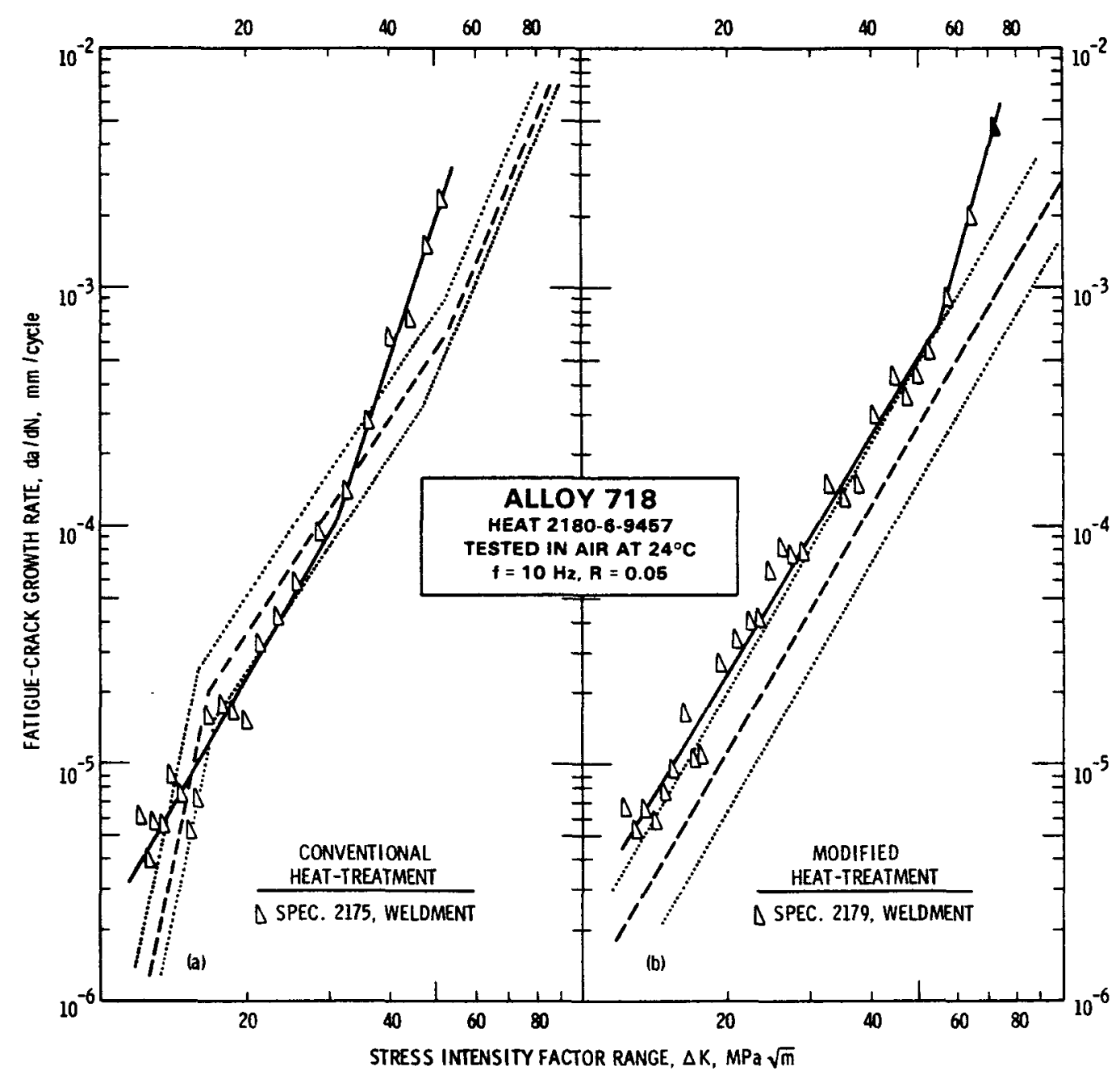

FIGURE 1. Comparison of Crack Growth Behavior in A1loy 718 Weldments and Wrought Product Forms (Sheet, P1ate, Bar, and Forgings) at $24^{\circ} \mathrm{C}$ $\left(75^{\circ} \mathrm{F}\right)$. Dashed 1 ines indicate regression lines for wrought material, and dotted lines indicate scatter bands for wrought material (Ref. 6). Neg. 8008383-1. 


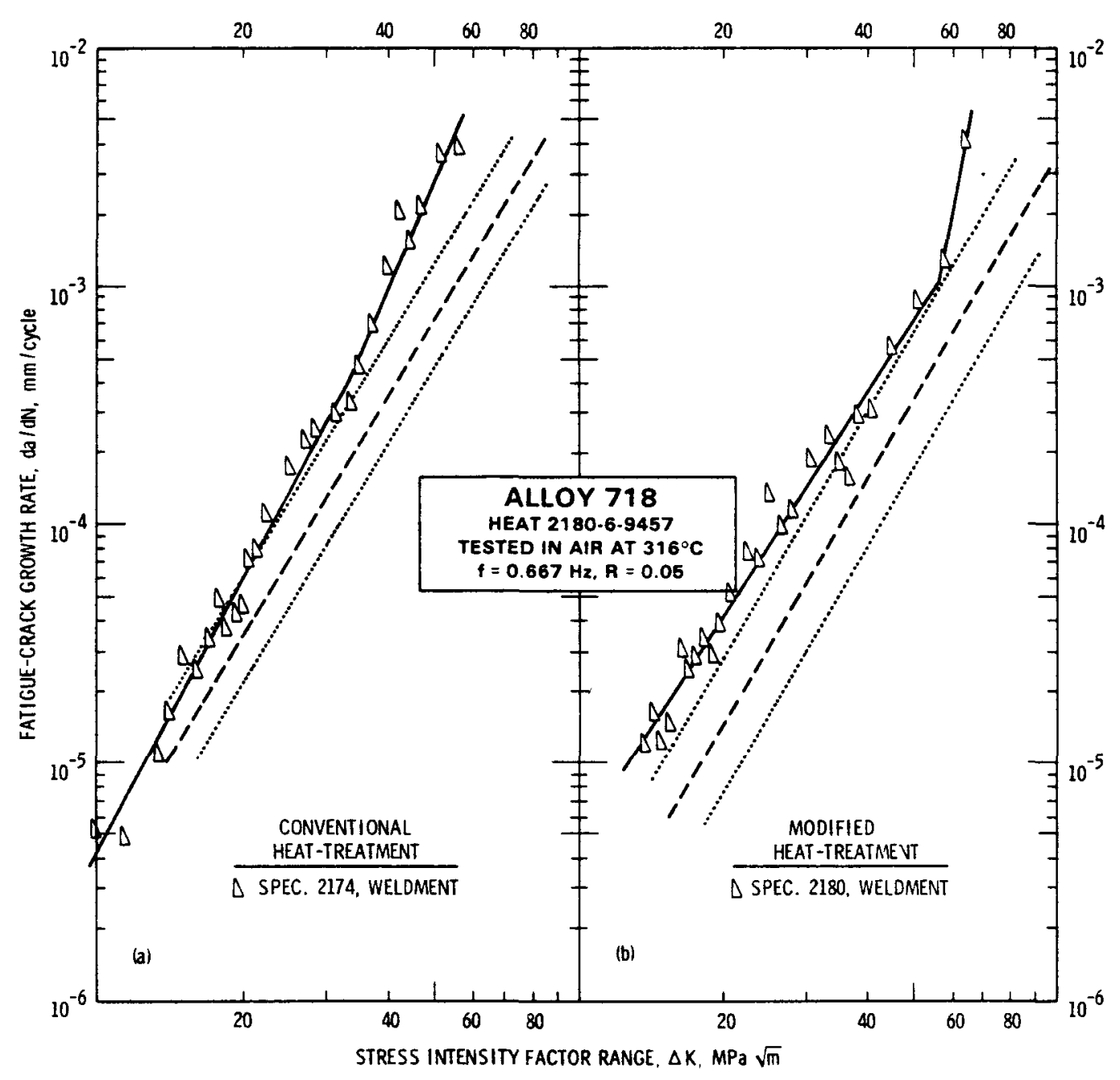

FIGURE 2. Comparison of Crack Growth Behavior in Alloy 718 Weldments and Wrought Product Forms (Sheet, Plate, Bar, and Forgings) at $316^{\circ} \mathrm{C}$ $\left(600^{\circ} \mathrm{F}\right)$. Dashed lines indicate regression lines for wrought material, and dotted lines indicate scatter bands for wrought material (Ref. 6). Neg. 8007779-7. 


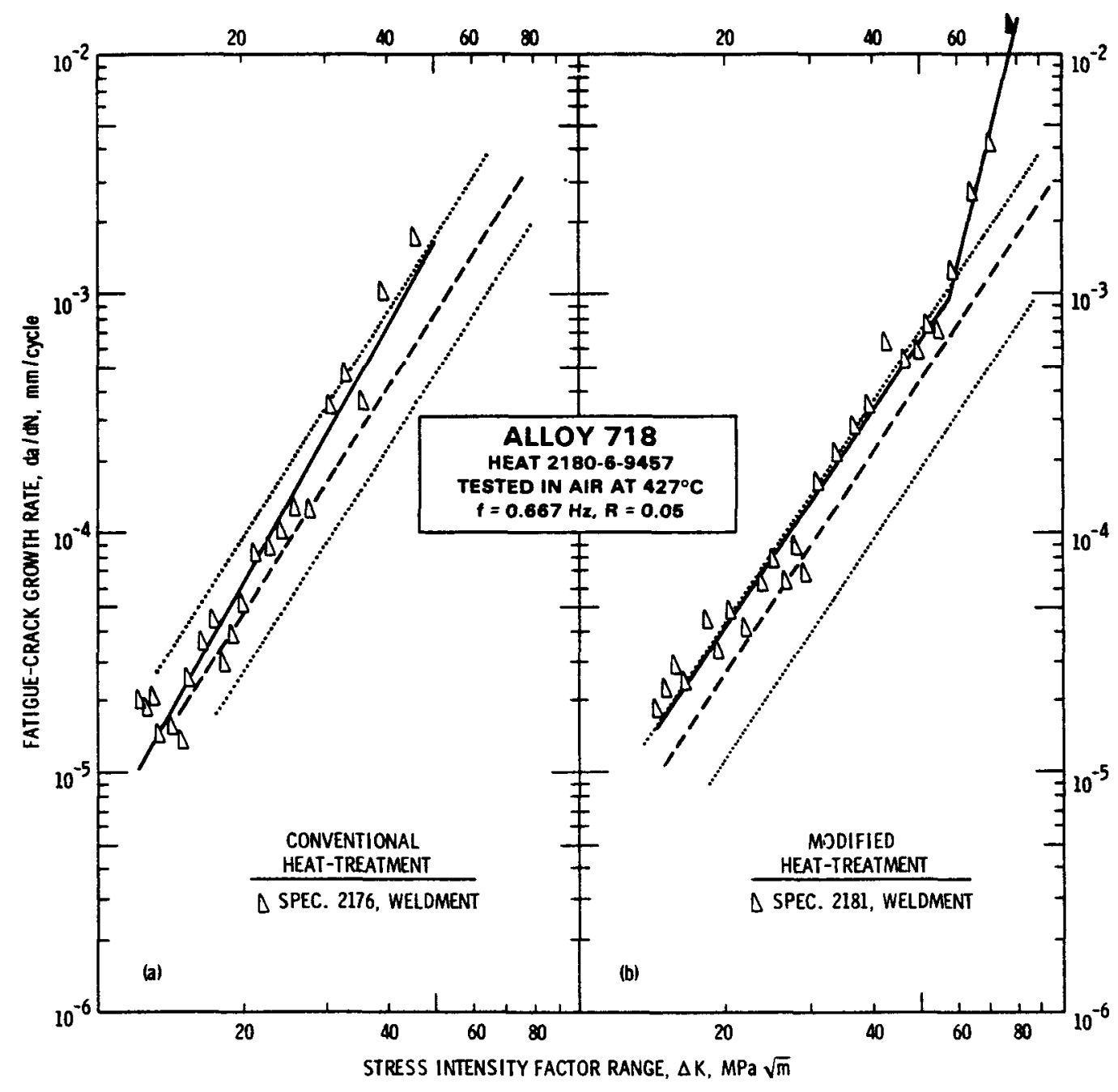

FIGURE 3. Comparison of Crack Growth Behavior in Alloy 718 Weldments and Wrought Product Forms (Sheet, Plate, Bar, and Forgings) at $427^{\circ} \mathrm{C}$ $\left(800^{\circ} \mathrm{F}\right)$. Dashed lines indicate regression lines for wrought material, and dotted lines indicate scatter bands for wrought material (Ref. 6). Neg. 8007779-5. 


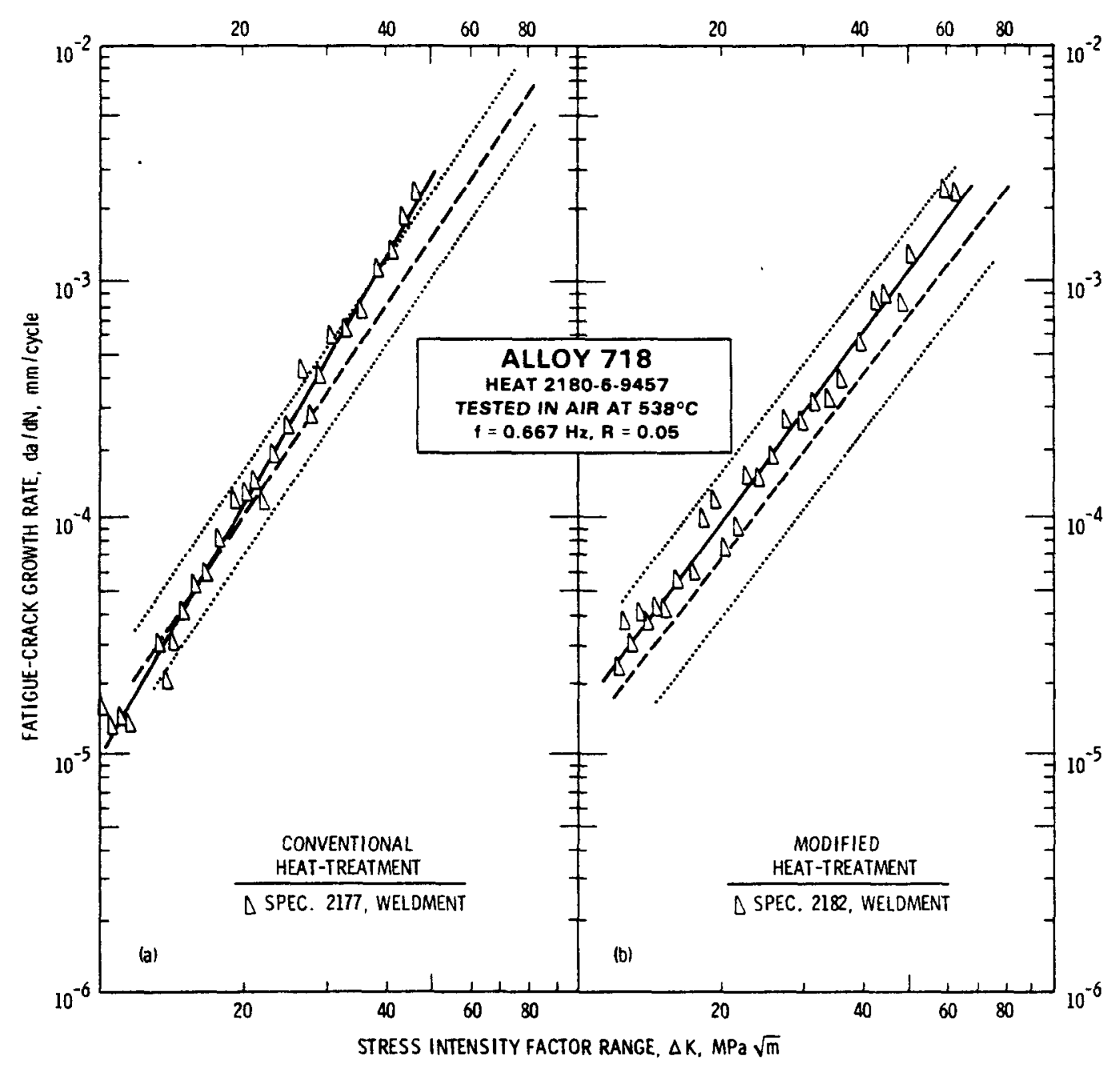

FIGURE 4. Comparison of Crack Growth Behavior in Alloy 718 Weldments and Wrought Product Forms (Sheet, Plate, Bar, and Forqings) at $538^{\circ} \mathrm{C}$ $\left(1000^{\circ} \mathrm{F}\right)$. Dashed lines indicate regression lines for wrought material, and dotted lines indicate scatter bands for wrought material (Ref. 6). Neg. 800779-4. 


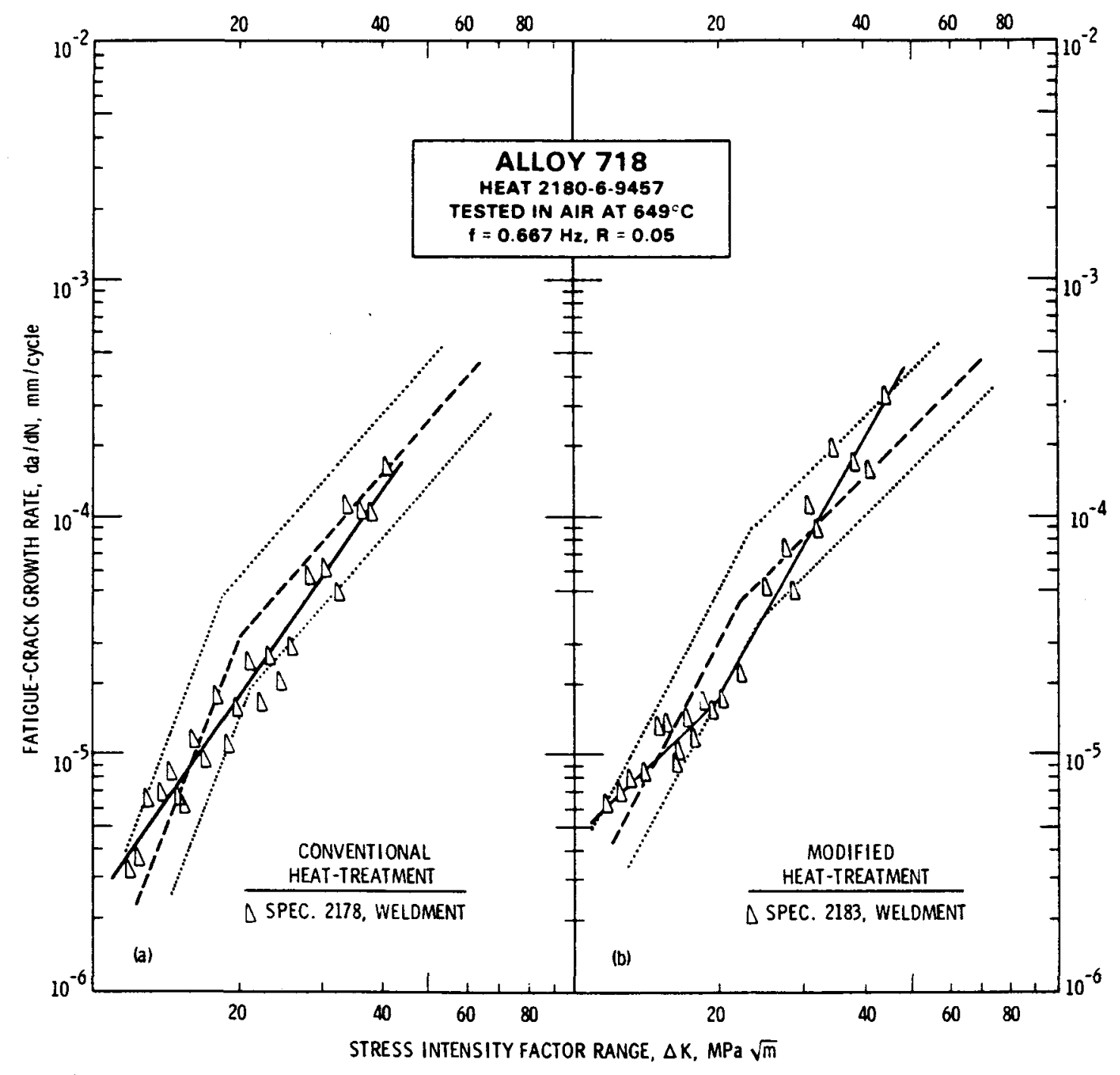

FIGURE 5. Comparison of Crack Growth Behavior in Alloy 718 weldments and Wrought Product Forms (Plate, Bar, and Forgings) at $649^{\circ} \mathrm{C}$ $\left(1200^{\circ} \mathrm{F}\right)$. Dashed lines indicate regression lines for wrought material, and dotted lines indicate scatter bands for wrought material (Ref. 6). Neg. P08722. 
product forms do not exhibit this tendency for a slope transition as strongly, and this is consistent with the observation that wrought forms of Alloy 718 generally have superior fracture toughness relative to weldments in Alloy $718 .{ }^{(13)}$

Reference 12 suggested that there was somewhat greater data scatter associated with the testing of Alloy 718 weldments than with the testing of Alloy 718 plate. However, the results of the regression analyses shown in Table 3 suggest that this is not always the case. The three measures of data variability (standard error of estimate, correlation coefficient, and scatter factor) do not indicate a consistent trend in the comparison between weldments and wrought product forms. Weldments may exhibit greater data variability for some heat-treatment/test temperature conditions, while the wrought product forms may exhibit greater variability for others. Hence, no general statements may be made concerning the relative variability in data for weldments. Reference 9 suggested that, for a single well-behaved heat of steel tested in air at room temperature, the scatter factor is approximately 2.0 for intralaboratory tests and approximately 3.0 for interlaboratory tests. Reference 14 suggested somewhat higher scatter factors (approximately 2.75 for a single heat of stainless steel) associated with elevated temperature testing. Table 3 shows scatter factors both higher than, and lower than, 2.75 and it is entirely possible that this degree of scatter is normal for regressions involving multiple specimens of Alloy 718. (The average scatter factor for the 29 regressions listed in Table 3 is 2.560.) 
TABLE 3

CRACK GROWTH EQUATION CONSTANTS (a)

$\frac{d a}{d N}=c(\Delta K)^{n}$ or $\log (d a / d N)=\log C+n \log (\Delta K)$

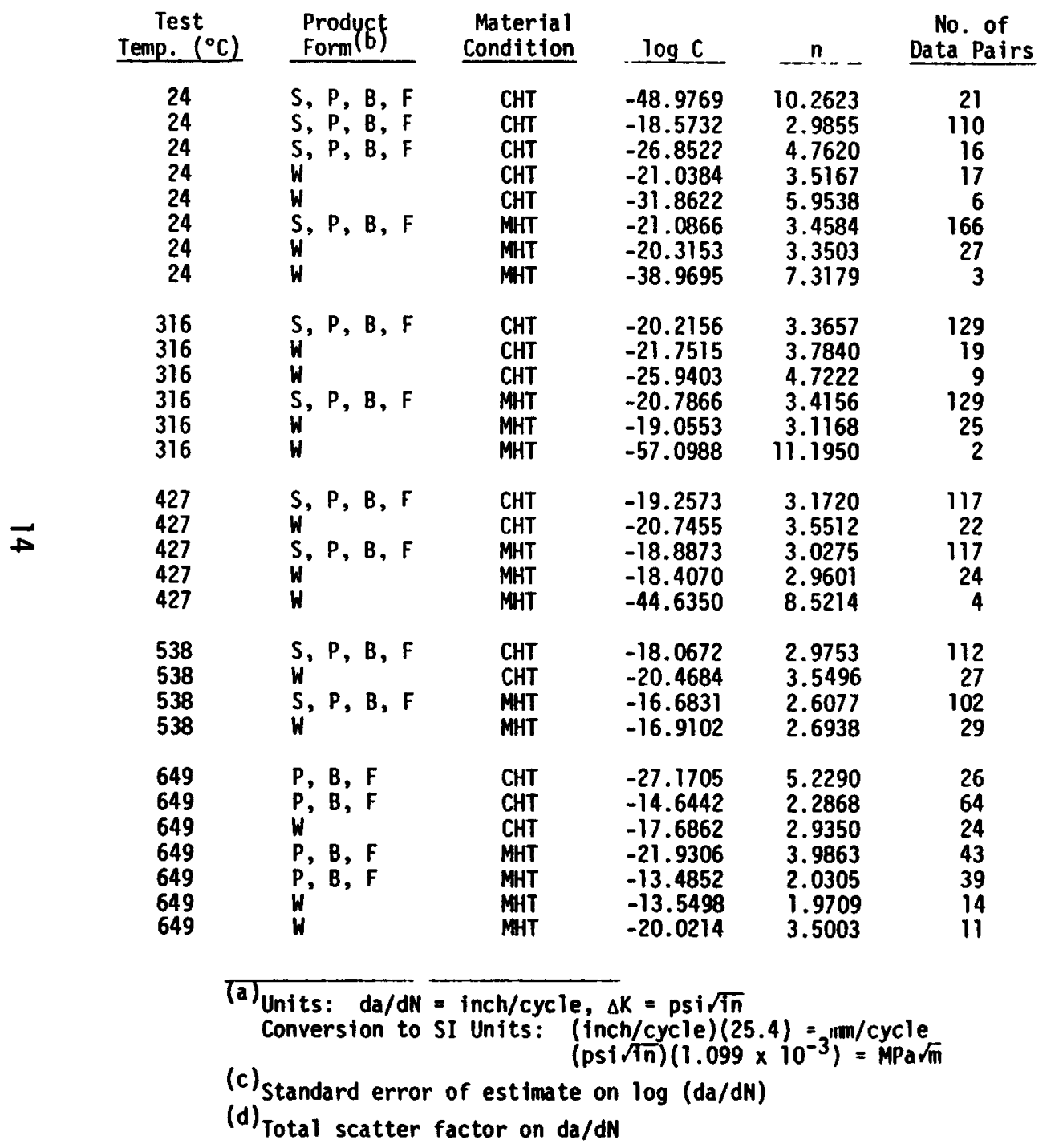

Standard Correlation

Scatter

\subsection{1}

0.0702

0.0662

0.9359

0.9359
$0 \quad 9877$

0.1164

0.9788

0.9715

0.0940

0.9917

0.1100

0.9910

0.0022

0.9864

0.9999

0.1028

0.0921

0.9855

0.1192

0.1014

0.9868

0.9562

0.9862

Factor (d)

- Data Range -

1.0000

0.1414

0.9708

0.1449

0.9736

0.1492

0.9732

0.9831

0.0956

0.9835

0.0747

0.9899

0.0796

0.9938

0.1216

0.9716

2.932

$11,630<\Delta K<15,070$ $15,070-\Delta K<45,740$ $45,740<\Delta K \quad 74,140$ $10,950<\Delta K<27,620$ $27,620<\Delta K<46,860$ $11,230<\Delta K-81,930$ 11, $060<\Delta K<50,316$ $11,060<\Delta K<50,316$
$50,316<\Delta K<65,370$

2.442

2.618

1.806

2.229

$13,630<\Delta K<66,680$ $8,940<\Delta K<29,170$ $29,170<\Delta K<51,060$ $14,010<\Delta K<77,120$ $12,160<\Delta K<51,220$ $51,220<\Delta K<57,910$

3.916

3.013

4.249

$13,510<\Delta K<62,230$ $11,020<\Delta K<41,250$ $13,010<\Delta K<88,050$ $13,040<\Delta K-52,020$ $52,020<\Delta K<69,760$

2.172

$11,820<\Delta K<66,000$

$9,190-1 K<41,280$ $12,030<\Delta K-62,850$ $11,050<\Delta K<56,840$

$12,580<\Delta K<18,090$

0.1678

0.8339

0.8990

0.9776

0.1060

0.9413

0.1085

0.9098

0.067

0.9273
0.9570

2.136
4.122

1.563

$18,090 \quad \Delta K<50,200$

$10,790<\Delta K<37,020$

$11,690<\Delta K<30,000$

$11,690<\Delta K<20,800$

$20,800<\Delta K<54,600$

$10,560<\Delta K<17,040$

0.1199

2.693

1.677

$17,040<\Delta K \cdot 39,400$

(b) s sheet

$\rho=$ Plate

$P=$ Plate
$B=$ Bar

= Forging

$w=$ Weldment 


\section{SUMMARY AND CONCLUSIONS}

The present study has shown that there is in most, but not all of the conditions examined, a slight increase in FCP rates in weldments relative to wrought product forms. This is evidenced by the slightly higher regression lines for the weldments. This increase is, however, not large and in several cases there is considerable overlap in the scatter bands for weldments and wrought product forms. Somewhat greater increases in FCP rates of weldments, relative to those in plate, were noted previously, $(11,12)$ but the comparisons were made between weldments from one heat, and plates from another. This introduces the possibility of at least some of the differences might be due to heat-to-heat variations in FCP behavior which have been identified in wrought Alloy $718 .^{(1-5)}$ By employing the same heat of material for all product forms, the present study was able to eliminate any consideration of heat-to-heat variability.

It has been suggested earlier, ${ }^{(12)}$ that there was increased data scatter associated with the testing of weldments, but the present study does not confirm this observation. The present results suggest no consistent trend in comparing data variability between weldments and wrought products tested over a wide range of heat-treatment/test temperature conditions. 
: 


\section{REFERENCES}

1. James, L. A. and Mills, W. J., Effect of Heat-Treatment and Heat-ToHeat Variations in the Fatigue-Crack Growth Response of Alloy 718 Part 1: Macroscopic Observations, Report HEDL-TME 80-9, Hanford Engineering Development Laboratory, Richland, WA, 1980.

2. Mills, W. J. and James, L. A., Effect of Heat-Treatment and Heat-ToHeat Variations in the Fatigue Crack Growth Response of ATloy 718 Part 2: Microscopic Observations, Report HEDL-TME 80-10, Hanford Engineering Development Laboratory, Richland, WA, 1980.

3. Mills, W. J. and James, L. A., "Effect of Heat Treatment on Elevated Temperature Fatigue Crack Growth Behavior of Two Heats of Alloy 718," ASME Paper 78-WA/PVP-3, New York, December 1978.

4. Smith, H. H. and Michel, D. J., "Fatigue Crack Propagation and Deformation Mode in Alloy 718 at Elevated Temperatures, "in Ductility and Toughness Considerations in Elevated Temperature Service, Series MPC-8, pp. 225-246, ASME, 1978.

5. Sadananda, K. and Shahinian, P., "Effect of Microstructure on CreepFatigue Crack Growth in Alloy 718," Res Mechanica, Vol. 1, pp. 109$128,1980$.

6. James, L. A., The Effect of Product Form Upon Fatigue-Crack Growth Behavior in AlToy 718, Report HEDL-TME 80-11, Hanford Engineering Development Laboratory, Richland, WA, 1980.

7. Smolik, G. R. and Korth, G. E., Reference Heat of Alloy 718 for Department of Energy Programs, Report TREE-1253, EG\&G Idaho Inc., Idaho Fal1s, ID, 1978.

8. Smolik, G. R. and Reuter, W. G., Heat Treatment Investigations for Welded Inconel 718 Pressure Vessels for the Power Burst Facility, Report ANCR-1227, Aerojet Nuclear Company, Idaho Fa11s, ID, 1975.

9. Clark, W. G. and Hudak, S. J., "Variability in Fatigue Crack Growth Rate Testing," Journal of Testing and Evaluation, Vol. 3, No. 6, pp. 454-476, $197 \overline{75}$

10. James, L. A., Specimen Size Considerations in Fatigue-Crack Growth Rate Testing, Report HEDL-TME 78-99, Hanford Engineering Development Laboratory, Richland, WA, 1978.

11. James, L. A., Fatigue-Crack Propagation Behavior of Inconel 718, Report HEDL-TME 75-80, Hanford Engineering Development Laboratory, Richland, WA, 1975. 
12. James, L. A., "Fatigue-Crack Growth in Inconel 718 Weldments at Elevated Temperatures," Welding Journal Research Supplement, Vol. 57, No. 1, pp. $17 \mathrm{~s}-23 \mathrm{~s}, 1978$.

13. Mills, W. J., Effect of Heat Treatment on the Elevated Temperature Tensile and Fracture Toughness Behavior of Alloy 718 Weldments, Report HEDL-TME 80-18, Hanford Eng ineering Development Laboratory, Richland, WA, 1980.

14. James, L. A., "Effect of Heat-to-Heat and Melt Practice Variations Upon Fatigue Crack Growth in Two Austenitic Steels," in Properties of Austenitic Stainless Steels and Their Weld Metals, ASTM STP 679, pp. 3-16, 1979 . 
HEDL-TME 80-49

$U C-79 b, h$

\section{DISTRIBUTION}

UC-79 (130)

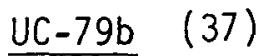

UC-79h (28)

DOE/RRT-HQ (2)

Mail Stop B-107

Washington, DC 20545

Program Division Director

DOE/FFTFPO

(5)

Director

HEDL (32)

LD Blackburn

KW Carison

BA Chin

DJ Criswell

AL Dittmer

AM Ermi

DL Greenslade

GW Hollenberg

JJ Holmes

WL Hu

LA James (2)

RL Knecht

DA Mervyn

WJ Mills

WE Roake

CT Schaedel

LK Severud

WF Sheely

JL Straalsund

AL Ward

JA Williams

GL Wire

$\mathrm{HH}$ Yoshikawa

Central Files (5)

Publ. Services (2)

S. Bergl in,

Contract Administration
$W / A-40$

W/A-40

W/A-58

W/A-40

W/A-40

W/A-58

W/A-40

W/A-59

W/A-58

$W / A-58$

$W / A-40$

$W / A-40$

$W / A-58$

W/A-40

$W / C-16$

W/A-46

W/C-98

W/A-62

W/A-57

W/A-40

W/A-40

W/A-58

$W / C-44$

$W / C-110$

W/C-115

W/A-21

\section{DO NOT MOROG:
THS PAGE}

